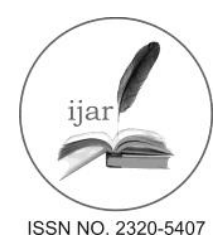

Journal homepage:http://www.journalijar.com
Journal DOI:10.21474/IJAR01

\section{RESEARCH ARTICLE}

INTERNATIONAL JOURNAL

OF ADVANCED RESEARCH

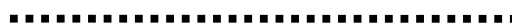

\title{
Impacts of bush fires on biodiversity of Sudanian and Zambezian savanna of the Democratic Republic of Congo - Case study on three protected areas: Upemba, Kundelungu and Garamba national parks, and Bombo-Lumene hunting domain from 2000 to 2014.
}

\author{
Eric Lutete Landu ${ }^{1}$, Constantin Lubini ${ }^{2}$, Jean Paul Kibambe Lubamba ${ }^{1}$, Marcelline Ngomba \\ Ndekelu ${ }^{1}$,Yannick Luya Wantuadi ${ }^{3}$ and Raymond Lumbuenamo Sinsi ${ }^{1}$. \\ 1. Dpt of Natural Ressources Management, Faculty of Agronomy, University of Kinshasa (RDC). \\ 2. Dpt of Environment Faculty of Sciences, University of Kinshasa (RDC). \\ 3. World Wildlife Fund, Democratic Republic of the Congo.
}

\section{Manuscript Info \\ Manuscript History: \\ Received: 12 May 2016 \\ Final Accepted: 19 June 2016 \\ Published Online: July 2016 \\ Key words: \\ Bushfires, protected area, national park, development. \\ *Corresponding Author}

Eric Lutete Landu.

\begin{abstract}
The Sudanian and Zambezian savanna of the Democratic Republic of Congo (DRC) are subject to annual bush fires. These fires cause heavy erosion of biodiversity in these ecosystems, which are also under increasing pressure from poaching of wildlife. The combined effect of these two threats to bioresources of the savanna ecosystem was analyzed in four protected areas: Upemba, Kundelungu and Garamba national parks, and BomboLumene hunting domain.

A frequency of 59122, 38474, 25279 and 6509 fire points was registered respectively in the 4 protected areas from 2000 to 2014. The highest intensity of bushfires was observed during the long dry season, with a variation of its incidence depending on the latitude. The effects of bush fires on biodiversity have been explained through the loss of habitat for wildlife species, with an estimate of 22067 hectares of forest cover lost during 14 years.

This study offers concrete solutions to prevent the spread of bushfires through thematic maps of bushfires hotspots detected in selected protected areas. Some strategies which recommend the use of bushfires as a sustainable management tool for natural resources management in DRC Sudan and Zambezian savannas are also proposed.
\end{abstract}

Copy Right, IJAR, 2013,. All rights reserved.

\section{Introduction}

Natural resources are under increasing anthropogenic pressures causing malfunctions of terrestrial ecosystems and loss of biodiversity. Amplified by unappropriated techniques and unsuitable resources utilization, these changes are directly impacting land use and landscape configuration (Bamba et al., 2008).

Forests and dry tropical savannas are the major habitat of biodiversity and ecosystem services in tropical regions. These ecosystems are widely used for livestock grazing, and are essential parts of the rural economy in many tropical countries. In most areas of the world, fire is considered part of the co-evolution of these ecosystems.

However, over recent decades, there has been a change in the historical fire regime. Fire became more frequent in these areas and is likely increasing with climate change. This is a serious threats to biodiversity, ecosystem processes, and rural economy (RamakantNayak, et al., 2014).

In the Democratic Republic of the Congo (DRC), while being a planning tool, bush fires are a major factor in the deterioration of protected areas in savanna ecosystems. They alter the structure and functioning of ecosystems by reducing forest cover due to plant mortality, soil destruction: structure change, fertility loss $\left(\mathrm{N}_{2}\right)$ and the destruction of living microorganisms (Ramade, 1982). They also have adverse effects on hydrological processes (increased runoff, low infiltration, high evaporation and clogging lowlands), disruption of middle regenerative capacity, 
reduction of biodiversity which is leading to a dynamic change in the atmosphere in terms of global warming due to air pollution through " $\mathrm{CO}_{2}$ " gases (Masahiro, 2003; Mbow, 2005; Dolidon, Caillault 2007 and 2009).

Indeed, rapid human population growth and depletion, the extensive degradation of socio-economic structures and different armed conflicts in the country are resulting in increasing exploitation of biological resources through techniques that generate negative impacts on biodiversity, including the practice of bush fires.

Despite its many adverse effects, bush fires have been considered as a factor subsequent to agricultural practices and to management of savannahs. It is therefore necessary to study its origin, spatiotemporal distribution and frequency (Mbow, 2004) in order to optimize the benefits derived from this practice and to guide the strategies for their management in protected areas. When well-managed, bush fire can be an appropriate tool for vegetation management and spatial planning.

This study, conducted from 2000 to 2014, is comparing the spatiotemporal distribution of bushfires in correlation with climatic seasons in three protected areas, in addition to determining the widespread loss of forest cover in terms of seasonal frequency and percentage.

The interest of this work is to make available to protected areas managers relevant information that will ever enable them to monitor bushfires and to use them as a land management tool for decision making regarding land planning and use. Furthermore, the approach of using bushfires during rainy seasons to minimize impacts on biodiversity, as recommended by this study can be applied in the development of strategies for reducing greenhouse gas emissions.

\section{Study area:-}

This paper focus its analysis on four protected areas covered from 2000 to 2014. The overall area covered by this study represents three biogeographic regions managed by the DRC wildlife authority named the InstitutCongolais pour la Conservation de la Nature (ICCN). These four protected areas as listed as follow: Upemba national park (1,773,000 ha) and Kundelungu national park (760 $000 \mathrm{ha}$ ) located in the area of Zambezian woodlands (miombo), Garamba national park (500,000 ha) belonging to the area of Sudanese woodlands and Bombo-Lumene hunting area (350 $000 \mathrm{ha}$ ) which is part of Guinean-Congolese savannas, at the borders of theZambezian area.

Each category is distinguished from others by its geophysical characteristics, flora and fauna.

\section{Upemba National Park:-}

Upemba National Park located is located between Haut-Lomami and Haut-Katanga in the DRC between $8^{\circ} 45^{\prime}$ and $9^{\circ} 05^{\prime}$ South latitude and $26^{\circ} 00$ 'and $27^{\circ} 10^{\prime}$ East longitude. It was established in 1939 and covers an area of 1773 ha. The park hosts varied landscapes with notched buttresses and vast plateaus. A significant portion of the park is formed by the Kamalondodepression and is home to two large lakes: Upemba and Kisale (Ardenne and Gaume. 2013). With a tropical climate and two clearly distinct seasons for a duration of six months each, the average annual rainfall varies between $1200 \mathrm{~mm}$ and $1500 \mathrm{~mm}$. The temperature in the dry season varies from $20^{\circ} \mathrm{C}$ to $22{ }^{\circ} \mathrm{C}$ on day times and runs down to $8^{\circ} \mathrm{C}$ at night.

\section{Kundelungu National Park:-}

Kundelungu National Park, located in the Haut-Katanga Province between $10^{\circ} 15^{\prime} 00^{\prime}$ South latitude and $27^{\circ} 36^{\prime}$ 00" East longitude, in north of the city of Lubumbashi, was created by the law No. 70-317 of 30 November 1970 (IUCN / PACO, 2010). It is part of the Sudanese climatic zone with a dry season of 5 to 6 months and a rainy season which leads to an annual mean of 1200 and $1400 \mathrm{~mm}$ of rainfall and $12^{\circ} \mathrm{C}$ to $20^{\circ} \mathrm{C}$ temperature. Rivers along the gallery forest form a dense river network, draining water to the basin of Lufira catchment in West or Luapula in the East (Huart, 1991).

\section{Garamba National Park:-}

Garamba National Park is located in the Haut-UeleProvince in the northeast of the Democratic Republic of Congo (DRC) in the transition zone between moist forests of the Congo Basin and the Guinea-Sudanese savannahs of the Eastern Provinces between $28^{\circ} 48^{\prime} 30^{\prime \prime}$ East Longitude and $3^{\circ} 45^{\prime}$ North Latitude. The Garamba National Park (PNG) was created by the Royal Decree of $17^{\text {th }}$ March 1938 and covers an area of 490.000 ha. Garamba is bordered by three hunting domain: Azandes in the west, Mondo Missa in the East and GangalanaBodio in the south, covering an overall area of 1.250.000ha. Its northern boundary is superimposed on the border with Sudan, where it adjoins the Lantoto Game Reserve (IUCN, 2010). 
With a tropical climate, 3-4 months dry season and 9-months rainy season from March to November, with an average of $1500 \mathrm{~mm}$ annual rainfall and temperatures not normally exceeding $32^{\circ} \mathrm{C}$, while the maximum of $40{ }^{\circ} \mathrm{C}$ can be achieved in December, Garamba National park is drained by numerous rivers including: Garamba, Aka and Dungu which, in turn, joins the Uélé river.

\section{BomboLumene hunting domain:-}

Bombo-Lumene hunting domain was created through the Ministerial Decree No. 07 of February 10 respectively in 1968 and 1976 (IZCN 1982). Bombo-Lumene is located $120 \mathrm{~km}$ from one of the largest cities in Central Africa, namely Kinshasa. The high rainfall $(1500 \mathrm{~mm}$, four months of dry season) is typical of a Sudan-Guinean climate AW4 on Köppen typology (IUCN / PACO. 2010).

Faunal biodiversity of these four protected areas is rich, rare and unique for its touristic, scientific, socio-economic or cultural interests. There are many species, some endemic including Ceratotheriumsimumcattoni (White Rhinoceros north, endangered in Garamba Park). Some species of monkeys are populating the woodlands of Upemba National Park, the zebra (Equusburchellibohmi) and the Giraffe, forest and savanna elephants (Loxodontaafricanacyclotis, and Loxodontaafricanaafricana), forest buffalo ( Synceruscaffernanus), savannah buffalo (Synceruscafferacquinoctialis) and other ungulates.

For example, in Upemba National Park, Malaisse et al. (1999) reported a variety of more than 220 genera and 42 endemic plant species. In Kundelungu, the flora is enriched with a large batch of Afro-highland elements. In Garamba, flora species has some characteristics of Sudan woodland, such as Lophiralanceolata, Isoberliniadalziellii and Parkiabiglobosa.

Local communities in these four protected areas depend on agriculture, small livestock, carbonization, fishing and hunting. They are poor; and villages, especially in Upemba and Kundelungu are marked by recent insecurity: burned houses and bullet holes in the walls (Vanleeuwe et al, 2009). The high demographic growth coupled with the national and international demand for more natural resources are among the factors contributing to current unsustainable utilization of resources and to intersectoral competition for access to land and the use of these resources (Doumenge C., et al., 2015).

\section{Methodology:-}

MODIS (Moderate Resolution Imaging Spectroradiometer) satellite images 250-m spatial resolution have been used to collect data on bushfires hotspots in the four targeted protected areas. Two MODIS satellite sensors - Terra (since February $24^{\text {th }}, 2000$ ) and Aqua (since $4^{\text {th }}$ May 2002) - alternate day and night data acquisition through detection of energy emitted by active fires.

MODIS is designed with spectral and radiometric characteristics for observing fire, with a spatial resolution of $1 \mathrm{~km}$ at nadir. Fire detection is performed using a contextual algorithm that exploits the strong emission of fires in the near-infrared radiation and which is based on the brightness temperature from the channels 4 and 11 (Giglio et al., 2003).

The fire hotspots covering a period from 2000 to 2014 was collected and analyzed for the four protected areas. The analytical method consisted in to superimposing on each study area a regular grid of $11 \mathrm{~km} \mathrm{x} 11 \mathrm{~km}$. The mesh size was chosen to enable the measurement of surface percentages affected by fire with different expected values, so that the variable parameter was being recorded as a continuous measurement (Bucini G. and E. F. Lambin., 2002). For each cell, an impact analysis of bushfires was conducted to (1) calculate the monthly frequency of fires, (2) highlight the spatial distribution and density of hotspots, (3) determine the seasonality of active fire points and (4) identify the impact of fires on vegetation cover in the different protected areas selected.

The frequency, spatial and temporal distribution of active fire points allowed to identify the seasons of high fire presences. Monthly percentage of bushfires points was calculated and represented in graphs curve based on the following formula: 
Percentage of Monthly Fire Points $=\frac{\text { Number of active fire points for given month }}{\text { Total number of active fire points for current year }} X 100$

A frequency analysis has allowed the assessment of bushfires impacts on biodiversity. The analysis consisted in five steps below:

* For each protected area, annual bush fire are compiled and mapped;

* Fire points are extracted for each targeted area;

* Create an analytical grid covering the entire area, whose cells covers an area of $11 \mathrm{Kmx} 11 \mathrm{Km}$;

* A query is used to compute the fire frequency per grid cell and the possible causes of fires are analyzed;

* A quantitative symbology of the fire frequency is defined for display according to the period and the geographic distribution for the three study areas.

Using Global Forest Change data which mapglobal forest loss and gain at a spatial resolution of 30 meters from 20002014 (Hansen et al., 2013), annual area of forest loss per protected area over the 14 years were computed and an analysis was conducted to assess the relationships between the forest cover loss and the fire occurrences.

\section{Results:-}

The analysis of active fire points derived from MODIS allowed producing the maps of monthly frequency of fires, while highlighting the seasonality of fire incidence in different protected areas. The impact of these fires on biodiversity has been highlighted through the comparison with forest cover loss within each protected area surveyed.

\section{Intensity of fires and climatic seasons in protected areas:-}

The trend of bushfires intensity in the four protected areas is not uniform and varies from one year to another. Highest peaks of fire points were observed from 2010 to 2013 forUpemba and Kundelungu National Parks and BomboLumene hunting domain, and also in 2007, 2011, 2012and 2013 for the Garamba National Park.

Figure 3 below shows the increase of bushfires points in Upemba, Kundelungu and Garamba national parks while a less bushfire intensity is also observed in Bombo-Lumene Hunting domain due to the permanent monitoring, facilitated by its small size.

As presented in Figure 1, the seasonal analysis of fires shows that the most scored months for bushfires correspond generally to the long dry season that varies differently in the four protected areas: from May to October for Upemba and Kundelungu, from November to February for Garamba, and from mid-May to mid-September for BomboLumene. The other months correspond to the wet period which records low percentages of early fires, varying from one area to another.

The presence of fires observed in April and November in the two national parks south of the equator and in February and March in Bombo-Lumene hunting domain is explained by the presence of the short dry season which characterizes that annual period.

As mentioned by Mbow(2000), the gradual drying of herbaceous biomass in dry season is leading to a rapid increase of the fire rate. The months that recorded maximums percent of bushfires are: May, June, July and September for Upemba; May, June, July, August and sometimes September for Kundelungu; December, January and February for Garamba and finally July and August for BomboLumene. Sometimes, extreme temperatures, wind and intense drought during these months are increasing the rate of bush fires and make them difficult to be fully controlled. 


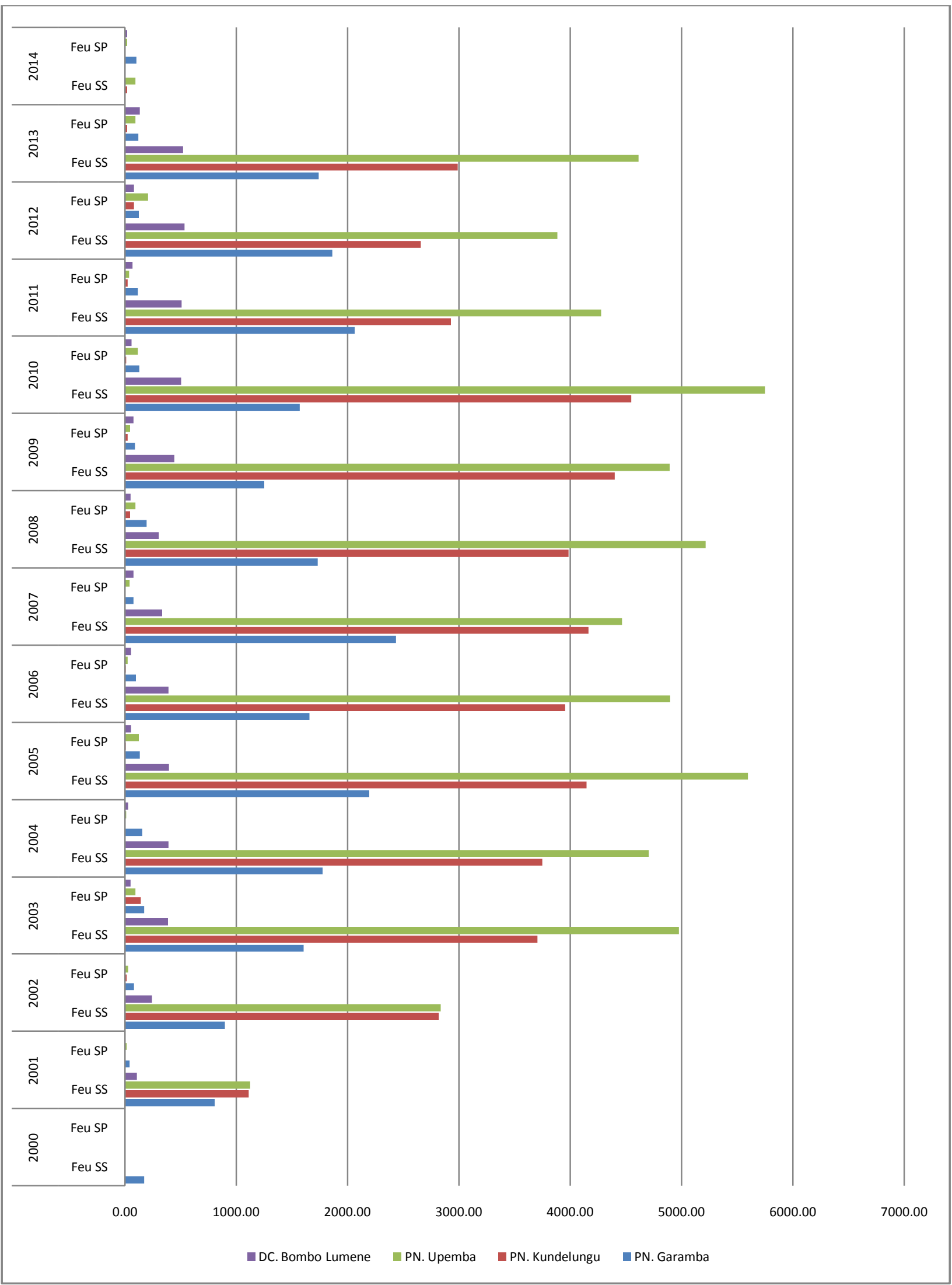

Figure 1: Seasonal intensity of bushfires from 2000 to 2014

Feu SSmeans dry season; and Feu SPmeans rainy season 


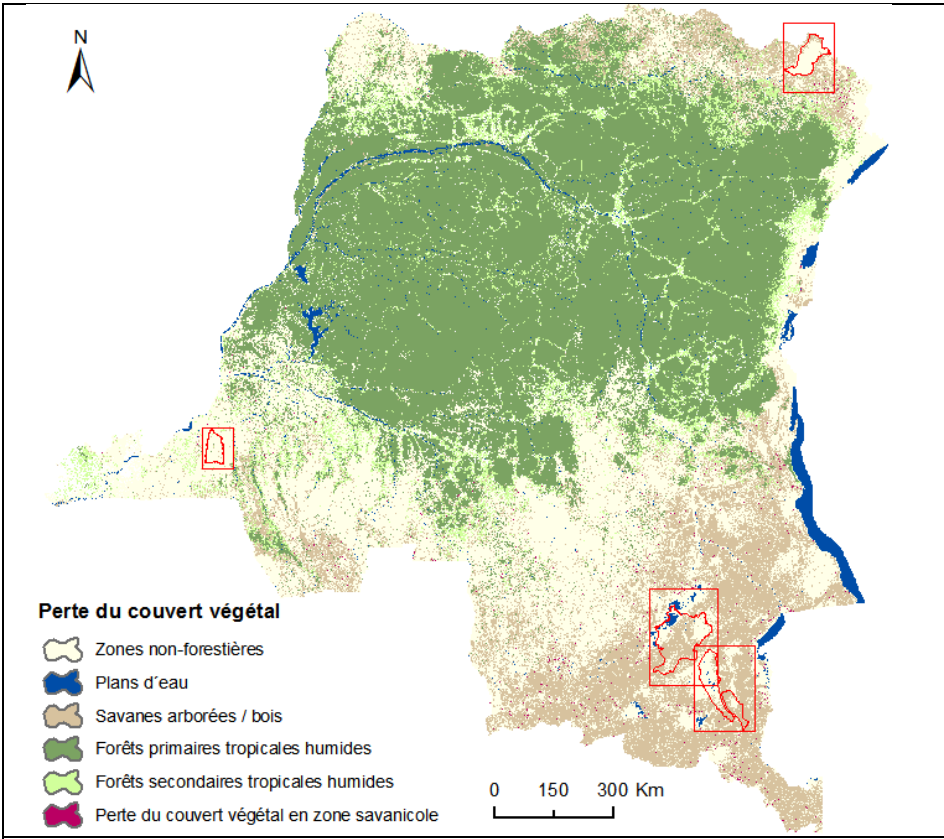

Figure 2 :Forest cover loss 2000-2014 (Facet/GFC DRC, OSFAC)

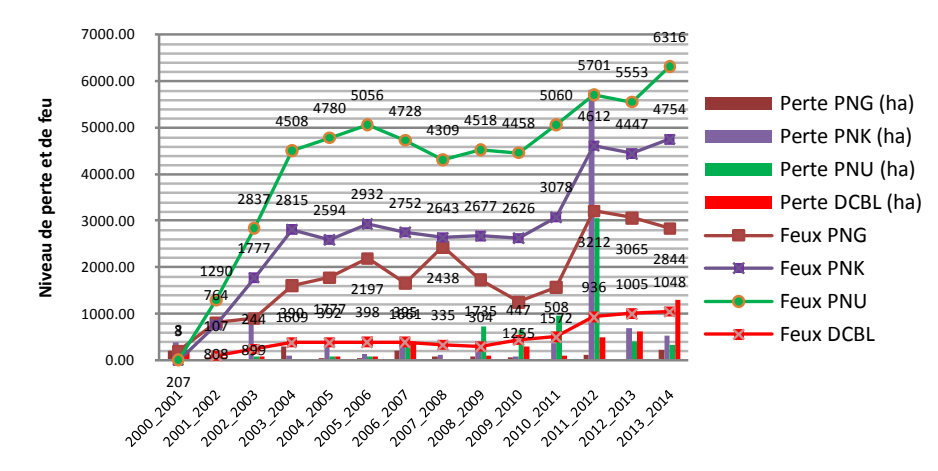

Années

Figure 6 :Evolution of losses and bushfires in 4 protected areas
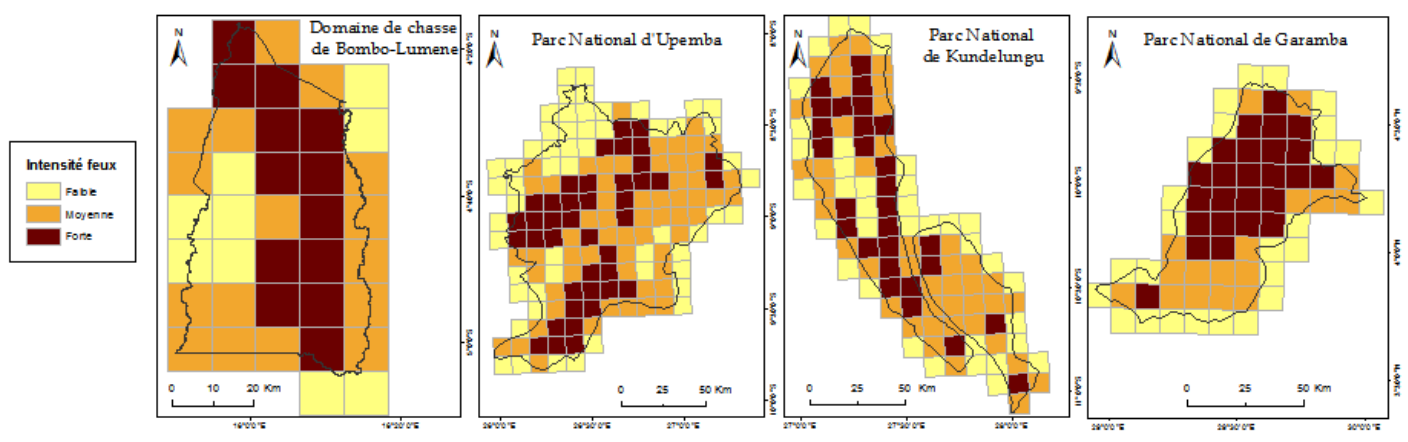

Figure 3: Intensity of fires per frequency during 14 study years (2000 to 2014)
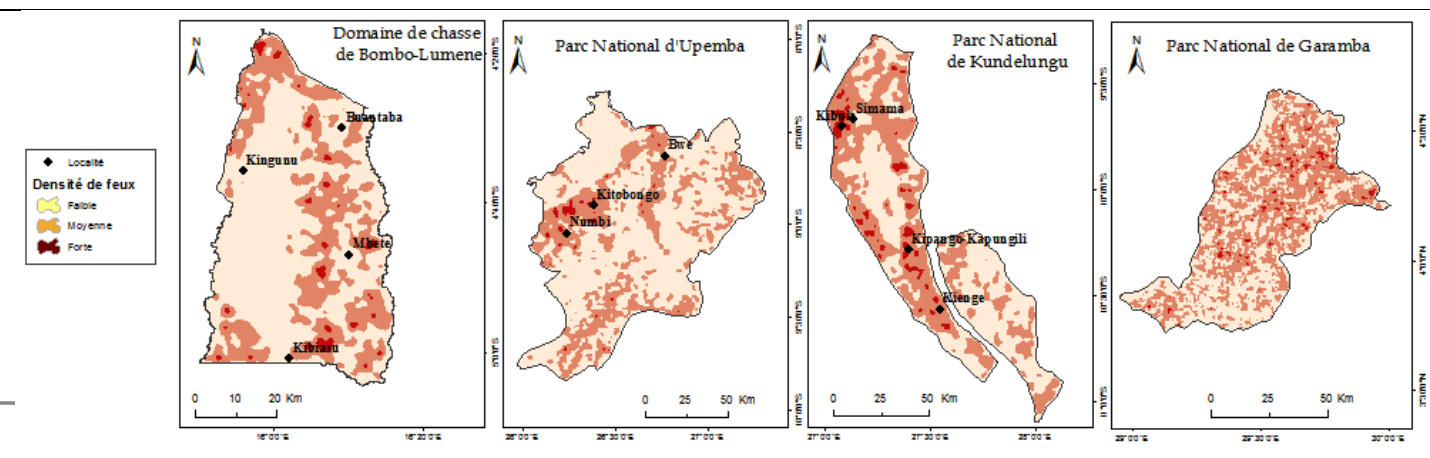

Figure 4 : Density of bushfires during 14 study years (2000 to 2014)
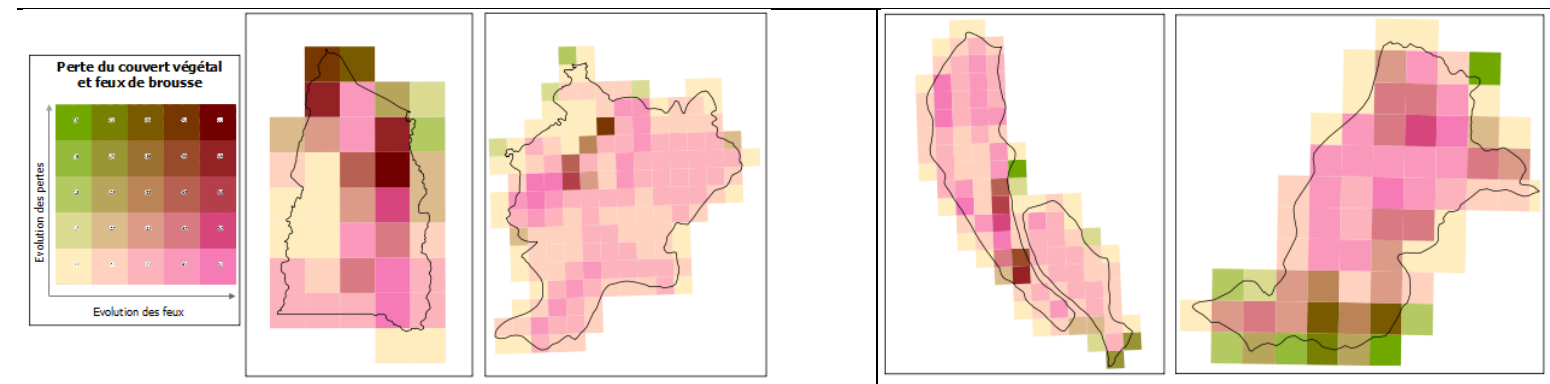

Figure 5 : Spatial correlation of losses and bushfiresduring 14 study years (2000 to 2014) 


\section{Evaluation of the impacts of bushfires on biodiversity:-}

This evaluation consisted mainly in analyzing the frequency and the spatial distribution of fires and determining the range of their threats and impacts to biodiversity and natural resources.

\section{Densities and frequency of bushfires in parks:-}

Regarding the spatial distribution of the annual brushfires points, the main characteristics listed below have been underlined:

* Taking into account the area of each protected area, 156 cells were analyzed for Upemba, 107 cells for Kundelungu, 68 for Garamba and 38 cells for Bombo-Lumene;

* For all four protected areas, areas with null rate of bushfires correspond to water surfaces;

* In Upemba National Park, analysis of spatial distribution of bushfires highlighted two specific zones. The first zone recorded weak density rates of bushfires, as shown through the density distribution of fires (Figure 4), which is linked to migratory flow of the surrounding human population within the park. This zone corresponds to the northwest of the protected area, boundaries of the park, swampy areas, gallery forests along the lake Upemba, and different water surfaces (rivers and lakes). These land covers types are playing the role of firewalls. The second zone recorded high density rates of bushfires, as shown on Figure 4 above. This zone corresponds to vegetation of grasses, therefore very flammable. These are also the areas where bushfires are made by the inhabitants Kitobongo, Numbi and Bwevillages.

* Regarding the Kundelungu National Park, this analysis highlighted three bushfires density classes: one of weak density observed in the northeast of the park; a second class of medium density observed in central parts of the park; and the third class characterized by the highest density covering the following villages: Kibula, Simama, Kipongo-Kipungili and Kienge. These villages have high human demographic rates and are facing intense anthropic activities which are likely impacting surrounding natural resources.

* In Garamba National Park, the density of bush fires is gradually increasing from bordering to central areas, even though these areas are weakly populated. These fires are likely made by people fleeing political unrest, wars and probably poaching that has intensified in recent years.

* Bombo-Lumene Hunting domain recorded weak rates in its integral conservation area, which is landlocked between two rivers: Bombo and Lumene, playing as natural barriers and firewalls. However, high density of bushfire points were encountered in the neighboring Kibiosu, Buantaba, Kingunu and Mbetevillages.

\section{Threats and impacts of bushfires:-}

The impact of these fires on biodiversity was highlighted by correlating the areas affected by fires with the loss of forest cover recorded in each area (Figure 5). Although this low correlation, it is evident that areas of high forest cover loss were also deeply affected by fires.

\section{Discussion And Suggestions:-}

The findings of this study show that the nature of bush fires in the selected four protected areas is closely linked to climatic seasons especially in the dry season, which recorded highest proportion of fires. During the dry period, low water content is reported on canopy, making easier the widespread of fires in some cases. In addition to climatic seasons, areas of high frequency have been located in nearby human settlements, showing that these fires are human-induced.

These findings align with conclusions early reported by van derWerf et al. (2010), Savadogo et al, (2007); Vasconcelos et al.(2009) and Furley et al. (2008), which stipulate that every year 2.5 Giga tones (Gt) of dry matter in African savannah is destroyed due to bushfires causing significant loss of natural resources and adverse impacts on wildlife and soil properties. In addition, fires increase gas emissions in the atmosphere (Furley et al., 2008).

Furthermore, a comparison of forest cover losses (Hansen et al., 2013) with areas mostly affected by bushfires shows that the forest degradation in the four protected areas of DRC savanna eco-regions is not entirely due to bush fires.

These findings show that considering the duration of this study, from 2000 to 2014, the following forest cover losses have been recorded in the protected areas: Upemba has shown a forest cover loss of 7,211.84 ha; 10546.66 ha for Kundelungu; 1636.47 ha for Garamba and finally 2672.02 ha for Bombo-Lumene.

The findings on Cerrado savannah and some dry parts of Africa have reported an increase in herbaceous species diversity or in other cases no change in diversity, in recurrent fire conditions (RamakantNayak and al., 2014). 
Although bushfires sometimes play a positive role in structuring ecosystems in tropical regions (Heinl and al., 2007), it is clear that it unfortunately constitute a serious threat to wildlife diversity of these four rich protected areas under study, particularly due to destruction of habitats and poaching.

Six suggestions below are made for the DRC wildlife authority, the InstitutCongolais pour la Conservation de la Nature (ICCN). ICCN should:

* Plan development activities in protected areas during the appropriate climatic seasons;

* Develop a monitoring program, an action plan and a national strategy for fire management in protected areas (example through using early fires);

* Build capacity of protected managers and staff trough different trainings related to sensitization of people living in and around these areas on the efficient use of bush fires;

* Establish an effective and well equipped monitoring service for the protection of natural resources, while increasing the number of eco-guards would be needed for law enforcement in protected areas against fires;

* Establish a monitoring and evaluation system which uses GIS and remote sensing tools for efficient data analysis of fire detection and evaluation of their impacts on biodiversity;

* Complete this study with field analysis to accurately determine the impacts of bushfires on wildlife and soil.

\section{Conclusion:}

Protected areas in DRC savanna eco-regions are constantly affected by bush fires whose repetitiveness and concentration at some points significantly impact the biodiversity through the destruction of forest cover and consequently the lives that depend on them.

This study focused on analyzing the spatial and diachronic distribution as well as, the impact of bushfires on biodiversity in four protected areas: Upemba, Kundelungu, and Garamba National Parks, and Bombo-Lumene Hunting domain from 2000 and 2014.

Frequency, density and forest cover loss maps derived for bushfires hotspots have shown the increasing threats the four protected areas are facing from practice of bush fires and these maps are effective decision tools for locating fires outbreaks in order to preserve and prevent sensitive areas, plan development and management activities.

Regime of bushfires in all protected areas in savanna area, as reported through these findings, is correlated with climatic periods. This fact should be taken into account when planning fires utilization as management tool by all stakeholders involving in protected areas management from grassroots level. This means that bushfires should be well planned during rainy season to minimize impacts on biodiversity.

\section{References:-}

1. Ardenne et Gaume., 2013. Parc \& Réserves : les aires protégées en République Démocratique du Congo. Volume 68, Fascicule 3, Viroinval (Belgique)

2. Bamba I., Mama A., Neuba D. F. R., Koffi K. J., Traore D., Visser M., Sinsin B., Lejoly J. \&Bogaert J., 2008. Influence des actions anthropiques sur la dynamique spatio-temporelle de l'occupation du sol dans la province du Bas-Congo (République Démocratique du Congo). Sciences \& Nature, University of AboboAjamé,Côte d'Ivoire, Volume 5: 49- 60 pp.

3. Caillault S., Ballouche A., Delahaye D., 2009. Organisation spatio-temporelle des feux de brousse : Approche comparative au Burkina Faso. Laboratoire Géophen, UMR 6554 LETG, CNRS/Université de Caen BasseNormandie Esplanade de la Paix, 14032 Caen cedex 18, France, 10 p.

4. Cassadon., 2012 Recensement aérien 2012, RDC, Parc National de la Garamba, ICCN/APN. 33 p.

5. DolidonH., 2007.La multiplicité des échelles dans l'analyse d'un phénomène d'interface nature/société : exemple des feux de brousse en Afrique de l'ouest. Cybergeo : European Journal of Geography [En ligne], Environnement, Nature, Paysage, article 363, mis en ligne le 08 mars 2007, consulté le 27 juin 2012. URL : http://cybergeo.revues.org

6. D. Oom et J.M.C. Pereira., 2012. Exploratory spatial data analysis of global MODIS active fire data", International Journal of Applied Earth Observation and Geoinformation

7. Doumenge C., Palla F., Scholte P., HiolHiol F. \&Larzillière A. (Eds.), 2015. Aires protégées d'Afrique centrale - État 2015. OFAC, Kinshasa, République Démocratique du Congo et Yaoundé, Cameroun : 256 p. 
8. G. Bucini et E.F. Lambin., 2002: "Fire impacts on vegetation in Central Africa: a remote-sensing-based statistical analysis"

9. Huart J.P., 1991. Conservation et réhabilitation des parcs nationaux de Kundelungu et d'Upemba, Rapport d'une mission d'évaluation dans le cadre du Projet 660-0125/GASPP de l'USAID. En ligne : http://www.bakasbl.org/news/zoom.php5?id=31 (consulté le 14/10/2012).

10. IZCN, 1982. Colloque sur l'ouverture du tourisme cynégétique dans les domaines de chasse au Zaïre, IZCNPUND-FAO, $47 \mathrm{p}$.

11. Malaise F., Baker A.J.M., Ruelle S., 1999.Diversity of plant communities and leaf heavy metal content at Luiswishicoper/cobalt mineralization, Upper Katanga, Dem. Rep. Congo. Biotechnol. Aron. Soc. Environ. 3 (2), 104-114 pp.

12. M. C. Hansen et al., 2013. High-Resolution Global Maps of 21st-Century Forest Cover Change

13. Masahiro O., 2003. Manuel sur la Lutte contre les Feux de Végétation: Compilation du Savoir-faire actuel. Série I: Les Techniques existantes dans la Lutte contre les Feux de Végétation, MINENVEF, Antananarivo, Madagascar, $112 \mathrm{p}$.

14. Mbow C., 2005. Utilisation des données basse et moyenne résolution (MODIS, SPOT4 VEGETATION) pour le suivi des feux de brousse et l'analyse du risque d'incendie au Sénégal. Journal des Sciences de l'Ingénieur, ESP-Dakar.5 : 67-77 pp.

15. M. Sow and Al., 2013 : "Fuel and fire behavior analysis for early-season prescribed fire planning in Sudanian and Sahelian savannas"

16. OSFAC, 2010. Étendue et perte du couvert forestier en République démocratique du Congo de 2000 à 2010 , Projet Forêt d'Afrique centrale évaluées par télédétection (FACET), publié par l'université d'Etat du Sud de Dakota, Etats-Unis, 63 p.

17. Ramade F., 1982. Éléments d'écologie végétale, éd. McGraw-hill, Paris, 445 p.

18. RajatRamakantNayak and Al, 2014 : "Fire and grazing modify grass community response to environmental determinants in savannas: Implications for sustainable use"

19. UICN/PACO, 2010.Parcs et réserves de la République Démocratique du Congo : évaluation de l'efficacité de gestion des aires protégées. Ouagadougou, BF: UICN/PACO, 149 p.

20. Vanleeuwe H., Henschel P., Moyer D., Gotanegre A., 2009. Recensement des grands mammifères \& impacts humains dans les parcs nationaux de l'Upemba \& de Kundelungu en RDC, United States Fish and Wildlife Service, Department of the interior, $30 \mathrm{p}$. 